\title{
Zinc deficient diet consequences for pregnancy and offsprings of wistar rats
}

\author{
Department of Pediatry, Escola Paulista de Medicina - São Paulo, Brazil
}

Adult female Wistar rats (90 days old; weight 180 to 220 grams) were submitted to different zinc deficient diets $(\mathrm{Zn}$; severe $=2.6$ $\mathrm{ppm}$; mild $=9.0 \mathrm{ppm}$ and normal diet $=81.6 \mathrm{ppm})$, during 6 weeks. After this time they were coupled with normal male Wistar rats. No differences regarding fecundity and sterility were observed between the groups. During pregnancy, part of the animals from severe and mild $\mathrm{Zn}$ deficient groups received the same diet and the others received normal diet. The animals from the group receiving normal diet, were divided into other 3 : the first received severe, the second mild $\mathrm{Zn}$ deficient diet and the third normal diet. During the study we observed that animals submitted to a $\mathrm{Zn}$ deficient diet (acute or chronic) had tendency to lower weight gain, lower weight of the offspring, lower serum levels of $\mathrm{Zn}$ in maternal and newborn (pool) blood. A significant reduction in the number of alive newborns was observed in the group of animals submitted to severe $\mathrm{Zn}$ deficiency. These data reinforces that $\mathrm{Zn}$ is a very important trace element overall during pregnancy.

UNITERMS: Zinc. Pregnancy. Offspring. Deficiency. Malformations.

\section{INTRODUCTION}

$\mathrm{B}$ ased on the studies of KEILIN \& MANN $(15,16)$, identifying the zinc $(\mathrm{Zn})$ as indispensable carbonic anhydrous component of the blood red corpuscles, around 200 metalloenzymes or metalloproteins were identified as $\mathrm{Zn}$ dependents in all Phyla $(1,29)$. It is believed that this number does not surpass 30 in the human

\section{Address for correspondence:}

Dirceu Solé

Av. Paes de Barros, 844 - apto. 61

São Paulo - SP - Brasil - CEP 03114-000 beings, also being present in some aldoses, deshydrogenases, peptidases and phosphatases (17), with participation in the metabolism of the carbohydrates, lipides and proteins mainly in synthesis and degradation of nucleic acids.

Depending on the period that the $\mathrm{Zn}$ deficient diet instals, the clinical evaluation can be variable. During the pregnancy, effects occur in a severe way and interfering with the action of the enzymes, dependent and necessary for the cellular division and reproduction (DNA and RNA polymerases, thymidinockinase), may lead to foetus death.

In this study we have evaluated the reflection of the different types of $\mathrm{Zn}$ deficient diets concerning Wistar rats pregnancy and offsprings. 


\section{MATERIAL AND METHODS}

Female Wistar rats, adults, 180 - 220 grams weight, were submitted, after 97 days born, to three diets during 6 weeks. These animals were kept in individual polypropilein cages, glassed floor and covered by steel, fixed to the cage by rubber tape. Received disionized water and special diet "ad libitum". They were classified in the following groups, according to the ration received: D - Ration with severe deficiency of $\mathrm{Zn}$ (2.6 ppm); M - Ration with moderate $\mathrm{Zn}$ deficiency (9.0ppm) and $\mathrm{C}$ - ration without deficiency of $\mathrm{Zn}$ (81.6ppm). After these 6 weeks period, they were coupled with normal males during 12 hours/night, being kept only the disionized water. Female Wistar rats presenting spermatozoids in the vaginal secretion were considerd "pregnant"(G) and continued under study forming the final seven groups, according to the ration received during the 21 days pregnancy: DGD - severe $\mathrm{Zn}$ deficiency before and during pregnancy; DGC - severe $\mathrm{Zn}$ deficiency before and ration control during pregnancy; MGM - Moderate deficiency before and no deficiency during pregnancy; CGD - severe deficiency during pregnancy only; CGM - moderate deficiency during pregnancy only and CGC - no deficiency before and during pregnancy. The female that did not become pregnant in the one week deadline period, even being coupled daily, were sacrified.

After 21 days pregnancy, rats were submitted to cesarea, under ethylic ether anesthesy, and their newborn constituted the RN groups according denomination of their mothers' group. At this moment, were observed the number of concepts (RN alive, natimorti, foetus reabsorptions) and the weight of the RN (offspring average). Samples of total heparinized blood (Liquimine ${ }^{\circledR}$ ) were collected from mothers through cardiac puncture and from the RN after decapitation ("pool") for the $\mathrm{Zn}$ levels determination, by spectrumphotometry of atomic absorption (Perkin-Elmer; wave length $213.8 \mathrm{~nm}$ ). Placentas were collected as well and, after dried in the glasshouse, $250 \mathrm{mg}$ of dried tissues were submitted to liquid digestion with a nitric-perchloric acid (2) mixture and to the determination of the $\mathrm{Zn}$ levels through spectrumphotometry of atomic absorption.

During the research, ingestion of ration and the ponderal evolution of the animals were followed. The deficient rations were produced in the Research Laboratory of the Pediatric Department of the Faculdade de Medicina in Botucatu, presenting a basic composition of $21 \%$ of proteins (28). $\mathrm{Zn}$ levels were controlled by the addition of a mineral salt mixture with a known $\mathrm{Zn}$ concentration.
Statistical analysis was performed through: Student "T" test, Kruskal-Wallis, Wilcoxon, and participation of the qui-square establishing alpha-5\%.

\section{RESULTS}

All the animals presented ponderal gain during pregnancy. However, animals submitted to the deficient diet presented moderate results (Tale 1). No difference was observed in the quantity of animals fecunded considering the initial type of ration received, $\mathrm{D}$ or $\mathrm{M}$ or C. Number of concepts (RN alive, natimorti or foetus reabsorption) was not different for all the other groups studied (Table 2). However, considering the number of RN alive, smaller values were observed between the animals of the DGB group (Table 2). The offsprings average weight in the different groups was almost the same (Table 1). About $65 \%$ of the animals whose mothers were submitted to deficient diet during pregnancy, presented paw malformations (fusion and ankles absence).

The $\mathrm{Zn}$ plasmic levels of the mothers pertaining to MGM group were meaningly smaller than the level of mothers pertaining to the MGC group. In the RN groups, differences were observed between the MGM < CGM groups (Table 1). No difference in the $\mathrm{Zn}$ placentary levels were observed (Table 1). No correspondence was observed between the maternal $\mathrm{Zn}$ levels, the "pool" of the RN and the placentary "pool"of the different groups studied.

\section{DISCUSSION}

The $\mathrm{Zn}$ nutritional deficiency has been described as associated to anorexia in a premature installation, dermatitis, alopecia and growth discontinuing. Generally, they will be more intensive according to the degree, duration and the period of life the deficiency was imposed. During pregnancy, lactation and wean, nutritional $\mathrm{Zn}$ needs are the maximum $(18,20,24,25,28)$.

We have observed in this research that, considering same weights in the begining of pregnancy, the ponderal gain of animals submitted to $\mathrm{Zn}$ acute deficiency (CGM and CGD) or chronic (DGD,MGM), was smaller than the informed by others $(4,7,8,11,18,22-25)$. It is agreed that the lower ponderal gain is consequence of smaller ingestion. Our animals consumed the same ration volume, fact that did not obligate us to criate "pair fed" groups. 
During the experience, we observed fur fall, diarreic occurrence and ulcerous lesions in tails, in the animals pertaining to several groups. In spite of descriptions on higher index of sterility and infecundity in females submitted to $\mathrm{Zn}$ diet deficiency $(3,12,22,25)$, this has not been observed in our animals. At the end of pregnancy, the number of concepts was not different from the several other groups. However, the number of $\mathrm{RN}$ alive in the DGD group was significantly smaller than the verified in the others (Table 2).

HURLEY \& TAO (11), studying Wistar rats during pregnancy, observed that only $68 \%$ of the animals submitted to an acute $\mathrm{Zn}$ diet deficiency $(0.4 \mathrm{ppm})$ had $\mathrm{RN}$ alive and $56 \%$ of the foetus implantation in the womb of the mothers were absorbed or death and $83 \%$ of the RN presented crude malformations. These results are confirmed by others $(8,18,23,24)$. Pregnancy itself, mainly when associated to $\mathrm{Zn}$ nutritional deficiency, is able to decrease the $\mathrm{Zn}$ serum levels and cause serious problems to foetus, since malformation till death $(3,5,10,14,26,32)$.

RECORD et col. (22) studied the $\mathrm{Zn}$ deficiency imposed to "Sprange-Fawley" rats during the first 11 days pregnancy. They concluded that $\mathrm{Zn}$ deficiency affects the cellules in large part in what refers to cellular division, mainly the lateral portion of the cranioneural tube and the tail region, justifying a higher incidence of malformations in the SNC.

In order to avoid any eventual misunderstanding in the evaluation of the RN animals, we made use of the offspring average weight. Poor diet animals showed tendency to lower weights. Generally, diets with more deficiency are usually followed by a weight reduction of the $\mathrm{RN}$. However this relation is not very clear when rations with limited deficiencies are used and that could probably be partially corrected by using maternal reserves $(7,11,23$ 25).

Determination of the $\mathrm{Zn}$ plasmatic levels in the pregnant rats, at the end of this period, showed smaller values for the MGM group animals in comparison the the MGC ones (Table 1).

$\mathrm{Zn}$ levels in "pool" of the RN plasma (Table 1), whose mothers were submitted to any kind of deficiency (acute or chronic, intensive or slight), showed tendency to lower values when compared to the control group (CGC). However, difference was only meaning in the MGM and CGC groups. These values were significantly higher than the ones of their mothers (Table 1). Similar occurrence has been verified in the human beings $(13,31)$.

According to PRASAD(21), maternal $\mathrm{Zn}$ would be transfered to foetus by active transportation through placenta. SIMMER et col. (27) by means of guinea-pigs, studied the ${ }^{65} \mathrm{Zn}$ distribution furnished to mother, through a foetusplacentary unit and observed the maintenance, in the $\mathrm{RN}$, of a higher gradient between the plasmatic and the muscular $\mathrm{Zn}$ of the $\mathrm{RN}$ in comparison to the maternal values. They also got similar ${ }^{65} \mathrm{Zn}$ concentrations in the maternal liver and foetus. Capacity of the $\mathrm{Zn}$ concentration by the placenta, observe one hour after the unique intravenous dose of ${ }^{65} \mathrm{Zn}$ was similar to the liver concentration. Through controled perfusion of the

Table 1

Main Characteristics Evaluated in Animals Pertaining to the Different Groups Studied (Average Data)

\begin{tabular}{|c|c|c|c|c|c|c|c|}
\hline \multirow[t]{2}{*}{ Variable } & \multicolumn{7}{|c|}{ Groups } \\
\hline & DGD & DGC & MGM & MGC & CGD & CGM & CGC \\
\hline Number & 11 & 10 & 13 & 8 & 11 & 8 & 8 \\
\hline Initial weight (g) & 214,30 & 221,60 & 225,10 & 227,80 & 223,90 & 218,60 & \\
\hline Final weight $(\mathrm{g})$ & 281,40 & 327,50 & 300,40 & 318,60 & 297,70 & 310,80 & 321,30 \\
\hline Nestful average weight (g) & 4,27 & 4,73 & 4,37 & 4,57 & 4,30 & 4,33 & 4,50 \\
\hline Plasmatic Zn (mg/dl) & 123,80 & 142,40 & $84,70^{*}$ & 151,00 & 113,60 & 139,70 & 137,60 \\
\hline Zn "pool" plasma RN (ug/dl)b & $274,20^{-}$ & 268,00 & $199,50^{*}$ & 253,30 & 222,70 & 263,20 & 347,00 \\
\hline Zn "pool" placenta (ug/g dry tissue) & 51,80 & 50,80 & 41,60 & 52,70 & 44,40 & 44,00 & 45,10 \\
\hline
\end{tabular}

Kruskal Wallis a,b - Plasmatic Zn MGM < MGC

Zn "pool" plasma RN - MGC < CGC

Wilcoxon - Plasmatic $\mathrm{Zn}<$ "pool" plasma RN - all groups 
Table 2

Quantity of concepts, after birth, alive and not, in the different groups studied

\begin{tabular}{lrrrr}
\hline Group & Alive & Not alive & Total & \% Alive \\
\hline DGD & 107 & 20 & 127 & 84.25 \\
DGC & 117 & 5 & 116 & 95.65 \\
MGM & 130 & 8 & 138 & 94.20 \\
MGC & 77 & 8 & 85 & 90.58 \\
CGD & 107 & 6 & 113 & 94.69 \\
CGM & 84 & 1 & 85 & 98.82 \\
CGC & 84 & 3 & 87 & 96.55 \\
TOTAL & 700 & 50 & 750 & 93.33 \\
\hline
\end{tabular}

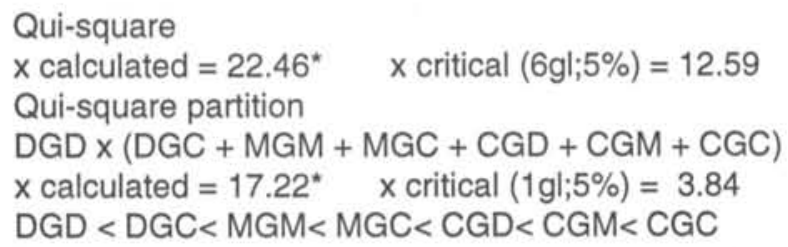

placentary tissue, they observed that the $\mathrm{Zn}$ mass transfered through the placenta was closely related with the plasmatic concentrations, that vary between 0.7 and $24.1 \mathrm{ug} / \mathrm{ml}$. Under normal conditions, daily transference of the $\mathrm{Zn}$ serum is of $0.12 \mathrm{mg} /$ day, quantity sufficient for foetus supliment and similar to the one incorporated to it in the last third part of the pregnancy. The authors conclude that the maternal foetus transfer suggests an active transport at maternal surface level, combined with slow liberation to the foetus, under a concentration gradient. Under normal conditions, $32 \%$ of plasmatic $\mathrm{Zn}$ circulates linked to alpha2 macroglobuline, $66 \%$ to albumine and in less quantity to aminoacids, mainly histidine and cysteine (9). ZIMMERMANN et col. (33) observed at the end of pregnancy in human beings, similar levels of albumine and inferior to alpha-2 macroglobuline in samples of maternal serum, when compared to the obtained through the umbilical vein. However, the $\mathrm{Zn}$ quantity per albumine/ gram was higher in the RN serum while in the one, linked to alpha-2, macroglobuline was higher in the maternal serum. This way, authors discussthe fact that the albumine should be the main protein transporter of $\mathrm{Zn}$ to the placenta. They consider that albumine is important for the $\mathrm{Zn}$ transport to tissues of rapid transference (for example intestine, liver and placenta) and that alpha-2 macroglobuline interacts with the cellules for the transport of $\mathrm{Zn}$ for complex metabolic requirements such as synthesis of DNA through foetus (33).

FAIRWEATHER-TAIT and col (8) in the serial of experiments with Wistar pregnant rats, submitted to a discrete $\mathrm{Zn}$ deficiency, observed a significant decrease in the $\mathrm{Zn}$ levels of placentary tissues of the deficient diet animals in comparison to those of the control group, on the 19th day of pregnancy. This lower placentary concentration of $\mathrm{Zn}$ resulted in a lower $\mathrm{Zn}$ total content in the foetus of these animals, although the placentary weight has showed higher than the one of the control group.

TERRY et col. (30) studying Zn placentary transport in pregnant female rabbits, in the third quarter of pregnancy, observed bigger ${ }^{65} \mathrm{Zn}$ passage through the placenta and a better foetus capture with the evolution of the pregnancy. The absence of ${ }^{65} \mathrm{Zn}$ in the placentary tissue made these authors define placenta as a transport organ and not a $\mathrm{Zn}$ reservatory. JOAQUIM (13) observed, in human beings, significantly higher levels of $\mathrm{Zn}$ in the placentary tissue in comparison to the maternal and $\mathrm{RN}$ serum, and does not believe, therefore, that placenta is a deposit organ, considering the higher $\mathrm{Zn}$ level found as a consequence, probably, of the growing that occurs in the placentary tissue until the end. According to METHFESSEL \& SPENCER (19), the homeostasis of $\mathrm{Zn}$ is regulated, mainly, through its secretion. Although $\mathrm{Zn}$ levels in foetus and in the respective placentas of the pregnant animals submitted to deficiency are lower than the one of the control group, FAIRWEATHER-TAIT observed a bigger $\mathrm{Zn}$ transference to foetus. This way, they affirm that under inadequate nutrition conditions of $\mathrm{Zn}$ the pregnant animal is able to mobilize the endogen $\mathrm{Zn}$ from metabolically active deposits such as the liver, and transfer it to foetus. 


\section{RESUMO}

Objetivo: Avaliar os efeitos da carência nutricional de zinco na gestação e prole de ratas Wistar.

Material e Métodos: Submetemos ratas Wistar adultas (90 dias) com peso entre 180 e 220 gramas a diferentes tipos de carência nutricional de zinco ( $\mathrm{Zn}$; grave: $2,6 \mathrm{ppm}$; moderada: $9,0 \mathrm{ppm}$ e sem carência $81,6 \mathrm{ppm}$ ) durante 6 semanas. Após esse periodo foram acasaladas com machos normais e não observamos diferenças quanto fertilidade e esterilidade entre os animais carentes. Durante a gestação, parte dos animais continuaram recebendo o mesmo tipo de ração e parte recebeu ração sem carência. Com relação ao grupo sem carência três outros grupos foram formados: um que passou a receber dieta com carência grave, outro moderada e o terceiro continuou sem carência.

Resultados e Conclusão: Observamos entre os animais submetidos à carência aguda ou crônica tendência a menor ganho ponderal durante a gestação, menor peso da ninhada, niveis séricos de $\mathrm{Zn}$ materno e de "pool" de RN mais baixos. Observamos de modo significante, menor número de RN vivos entre os animais submetidos à carência grave reforçando o papel do $\mathrm{Zn}$ durante a gestação.

\section{REFERENCES}

1. AGGET, P.J. - Physiology and metabolism of essential trace elements: an outline. Clin End Metab 14: 513-44, 1985.

2. AMANCIO, O.M.S. - Comportamento do cobre na desnutrição da gestante e no produto da concepção: Estudo experimental. São Paulo, 1981. (Tese de doutorado - Instituto de Ciências Biomédicas - Universidade de São Paulo).

3. APGAR, J. - Zinc and reproduction: an update. J Nutr Biochem 3: 266-278, 1992.

4. ASOKAN, P. \& CHERIAN, M.G. - Turnover of parenterally administered zinc and cadmium and the redistribution of metallothionein bound zinc in newborn rats. Toxicology 36 : 1-13, 1985 .

5. DREOSTI, I.; TAO, S.H. \& HURLEY, L.S. - Plasma zinc and leukocyte changes in weanling and pregnant rats during zinc deficiency. Proc Soc Exp Biol Med 127: 169-74, 1968.

6. ESSATARA, M.B.; LEVINE, A.S.; MORLEY, J.E. \& Mc CLAIN C.J. - Zinc deficiency and anorexia in rats: normal feeding patterns and stress induced feeding. Physiol Behav 32: 469-74, 1984a.

7. FAIRWEATHER-TAIT, S.J.; WRIGHT, A.J.A. \& WILLIAMS, C.M. - Zinc metabolism in pregnant and lactating rats and the effect of varying iron: $\mathrm{Zn}$ in the diet. Br J Nutr 52: 205-13, 1984.

8. FAIRWEATHER-TAIT, S.J.; WRIGHT, A.J.A.; GOOKE, J. \& FRANCLIN, J. - Studies of zinc metabolism in pregnant and lactating rats. Br J Nutr 54: 401-13, 1985.

9. HENKIN, R.I. - Metal-albumin-amino acid interactions: chemical and physiological interelationships. Adv Exp Med Biol 48: 299-328, 1974.
10. HURLEY, L.S. - Teratogenic aspects of manganese, zinc, and copper nutrition. Physiol Rev 62: 249-95, 1981.

11. HURLEY, L.S. \& TAO, S. - Alleviation of teratogenic effects of zinc deficiency by simultaneous lack of calcium. Am J Physiol 222: 322-5, 1972.

12. HURLEY, L.S. \& SWENERTON, H. - Congenital malformations resulting from zinc deficiency in rats. Proc Soc Exp Biol Med 123: 692-6, 1966.

13. JOAQUIM, M.C.M. - Níveis de zinco no sangue de mães, na placenta, no sangue de recém-nascidos de termo com peso adequado, pequeno e grande para a idade gestacional e prétermo com peso adequado para a idade gestacional. São Paulo, 1987. (Tese de Doutorado - Escola Paulista de Medicina).

14. KEEN, C.L. - Maternal factors affecting teratogenic response: a need for assessment. Teratology 46: 15-21, 1992.

15. KEILIN, D. \& MANN, T. - Carbonic Anhydrase. Nature 144: 442-3, 1939.

16. KEILIN, D. \& MANN, T. - Carbonic Anhydrase. Purification and nature of the enzyme. Biochem J 34:1163-76, 1940.

17. KIRCHGESSNER, M.; SCHWARZ, F.J. \& SCHNEGG, A. - Interactions of essential metals in human physiology. In: PRASAD, A.S. (ed) Clinical, Biochemical and nutritional aspects of trace elements. New York, Liss, 1982. p.477512 .

18. MASTERS, D.G.; KEEN, C.L.; LONNERDAL, B. \& HURLEY, L.S. - Release of zinc from maternal tissues during zinc deficiency or simultaneous zinc and calcium deficiency in the pregnant rat. J Nutr 116:2148-54, 1986.

19. METHFESSEL, A.H. \& SPENCER, H. - Zinc metabolism in the rat II. Secretion of zinc into intestine. J Appl Physiol 34: 63-7, 1973. 
20. PEREZ-JIMENEZ, F.; BOCKMAN, D.E. \& SINGH, M. Pancreatic acinar cell function and morphology in rats fed zinc-deficient and marginal zinc-deficient diets. Gastroenterology 90:946-57, 1986.

21. PRASAD, A.S. - Zinc a short review. Ann Nestlé 33:19-33, 1974.

22. RECORD, I.R.; TULSI, R.S.; DREOSTI, I.E. \& FRASER, F.J. - Cellular necrosis in zinco-deficient rat embryos. Teratology 32: 397-405, 1985.

23. REINSTEIN, N.H.; LONNERDAL, B.; KEENC, L. \& HURLEY, L.S. - Zinc copper interactions in the pregnant rat: fetal outcome and maternal and fetal zinc, copper and iron. J Nutr 114:1266-79, 1984.

24. ROGERS, J.M.; KEEN, C.L. \& HURLEY, L.S. - Zinc deficiency in pregnant Long-Evans hooded rats: teratogenicity and tissue trace elements. Teratology 31: 89$100,1985$.

25. SANDSTEAD, H.H. - Zinc deficiency a public health problem? Am J Dis Child 145: 853-9, 1991.

26. SATO, F.; WATANABE, T.; HOSHI, E. \& ENDO, A. Teratogenic effect of maternal zinc deficiency and its coteratogenic effect with cadmium. Teratology 31: 13-8, 1985.

27. SIMMER, K. \& THOMPSON, R.P.H. - Zinc in the fetus and newborn. Acta Paediatr Scand 319: 158-63, 1985.
28. SOL, D. - Estudo da carência nutricional de zinco em ratas adultas não gestantes, gestantes e seus recém-nascidos. São Paulo, 1987 (Tese de Doutorado - Escola Paulista de Medicina) São Paulo.

29. SZERDAHELI, P. \& KASA, P. - Histochemistry of zinc and copper. Int Rev Cytol 89: 1-33, 1984.

30. TERRY. C.W.; TERRY, B.E. \& DAVIS, J. - Transfer of 65 zinc across the placente and fetal membranes of a rabbit. Am J Physiol 198: 303-8, 1960.

31. TRINDADE, C.E.P.; SARTOR, M.E.A.; TONETE, S.S.Q.; ZULIANI, A.; NàBREGA, F.J.; RUDGE, M.V.C. \& CURI, P.R. - Zinco no soro de mães e de cordão de recém nascidos de termo com pesos adequados, termo com pesos baixos e de pré-termo com pesos adequados para a idade gestacional. Rev Paul Pediatr 1: 10-3, 1983.

32. VILLA-ELIZAGA, I. \& CUNHA FERREIRA, R.M.C. Zinc, pregnancy and parturition. Acta Paediatr Scand 319: 150-7, 1985.

33. ZIMMERMAN, A.W.; DUNHAM, B.S.; NOCHIMSON, D.J.; KAPLAN, B.M.; CLIVE, J.M. \& KUNKEL, S.L. - Zinc transport in pregnancy. Am J Obstet Gynecol 149: 523-9, 1984. 